\title{
The effect of different flow regimes on the growth and metabolic rates of the scleractinian coral Galaxea fascicularis
}

\author{
M. Schutter $\cdot$ J. Crocker $\cdot$ A. Paijmans $\cdot$ M. Janse $\cdot$ \\ R. Osinga $\cdot$ A. J. Verreth $\cdot$ R. H. Wijffels
}

Received: 30 October 2009/Accepted: 13 March 2010/Published online: 20 April 2010

(C) The Author(s) 2010. This article is published with open access at Springerlink.com

\begin{abstract}
To study the effect of water flow on coral growth, four series of ten coral nubbins of Galaxea fascicularis were exposed to four different flow regimes $(0,10,20$, and $25 \mathrm{~cm} \mathrm{~s}^{-1}$, bidirectional flow) for 42 weeks. Buoyant weight, surface area, and polyp number were measured at regular intervals. Net photosynthesis and dark respiration were measured at the corresponding flow speeds, and daily amount of photosynthetic carbon left for coral growth was calculated. Finally, skeletal density and CN content, chlorophyll concentration and dry weight of coral tissue were determined for each coral. Specific growth rate in day $^{-1}$ ) decreased with time in each flow treatment. Absence of flow resulted in significantly lower growth rates. Average specific growth rate calculated over the entire experiment was not significantly different between 10 and $20 \mathrm{~cm} \mathrm{~s}^{-1}$, while it was significantly higher at $25 \mathrm{~cm} \mathrm{~s}^{-1}$. From 10 to $25 \mathrm{~cm} \mathrm{~s}^{-1}$, average net photosynthetic rate decreased and average dark respiration rate did not change significantly. Scope for growth based on phototrophic carbon decreased with increasing flow. Growth was not positively correlated with either photosynthesis or respiration, or scope for
\end{abstract}

Communicated by Environment Editor Prof. Rob van Woesik

M. Schutter · J. Crocker · A. Paijmans · R. Osinga ( $₫)$. A. J. Verreth

Aquaculture and Fisheries Group, Wageningen University, P.O. Box 338, 6700 AH Wageningen, The Netherlands

e-mail: Ronald.Osinga@wur.nl

M. Schutter · R. H. Wijffels

Bioprocess Engineering, Wageningen University,

P.O. Box 8129, $6700 \mathrm{eV}$ Wageningen, The Netherlands

M. Janse

Burgers Zoo, Antoon van Hooffplein 1, 6816 SH Arnhem,

The Netherlands growth. It is suggested that higher flow rates reduce the chance of disturbance of coral growth by competing algae or cyanobacteria, allowing corals to grow more readily with the maximum specific growth rate possible under the given environmental conditions. Notably, other effects of increased flow, such as increased respiratory rates and increased (in)organic nutrient uptake, might have been equally responsible for the increased growth of the corals in $25 \mathrm{~cm} \mathrm{~s}^{-1}$.

Keywords Coral growth - Water flow · Photosynthesis . Respiration · Galaxea fascicularis

\section{Introduction}

Water flow is one of the most important abiotic factors influencing the growth of sedentary marine invertebrates (Sebens 1987). Particularly interesting is the effect of flow on the growth and metabolism of zooxanthellate scleractinian corals, because of the complex physiology of these animals. Zooxanthellate scleractinian corals live in symbiosis with unicellular algae, known as zooxanthellae, that translocate part of the carbon that is fixed during photosynthesis to their animal host. This symbiotic relationship allows the coral to benefit from both heterotrophic and phototrophic carbon sources.

The importance of water flow for different aspects of coral biology has received considerable attention. Water flow affects physiological processes such as photosynthesis and respiration by relieving diffusion limitation for dissolved gasses (Dennison and Barnes 1988; Patterson et al. 1991; Patterson 1992; Atkinson et al. 1994; Lesser et al. 1994; Shashar et al. 1996; Bruno and Edmunds 1998). Flow also affects the encounter and ingestion rate of food 
particles (Helmuth and Sebens 1993; Sebens 1997; Sebens et al. 1997, 1998), the uptake of dissolved inorganic nutrients such as nitrate, phosphate (Stambler et al. 1991; Atkinson and Bilger 1992; Thomas and Atkinson 1997), and the uptake of inorganic carbon (Lesser et al. 1994). Third, flow aids in removal of harmful waste products such as oxygen radicals or its derivatives (Nakamura and van Woesik 2001) and in removal of sediments or nuisance algae and cyanobacteria that might otherwise suffocate corals (Rogers 1990; Anthony and Fabricius 2000; Box and Mumby 2007). On the other hand, water flow can also have negative effects on coral biology, for example by stressing the coral (Jokiel 1978) by damaging the delicate coral tissue, by breaking off branches of skeleton, or by restricting particle capture due to deformation and flattening of the tentacles (Sebens et al. 1997). Growth rates of corals grown under different flow regimes will thus be a consequence of the sum of effects that flow exerts on coral physiology. The different processes affected by flow (i.e., feeding efficiency, gas exchange, and waste removal) may each have their optimum at a different flow rate. Furthermore, optimal flow rates may vary among species and even among conspecific individuals. Indeed, some corals have been found to grow more rapidly when flow increases (Jokiel 1978; Montebon and Yap 1997; Nakamura and Yamasaki 2005), while other corals were found to have comparable growth rates (Sebens et al. 2003), or even decreased growth rates (Kuffner 2001). Khalesi et al. (2007) found a hyperbolic profile of growth with increasing flow rate for a soft coral.

Most studies on the effects of flow on either growth or metabolic rates often examined only "low" and "high" flow treatments and did not characterize their flow regimes with a meaningful number for flow speed, or they examined only a limited range of flow speeds (e.g., Sebens et al. 2003, 0-10 $\mathrm{cm} \mathrm{s}^{-1}$ ). Besides that, different coral speciesthat might respond differently to flow speed-were used in previous studies, thus making it difficult to compare results. Therefore, from the available data, it is hard to deduce the response of a single coral species to a wide range $\left(>10 \mathrm{~cm} \mathrm{~s}^{-1}\right)$ of flow regimes.

The first aim of this work was to study the effect of water flow on the (skeletal) growth of Galaxea fascicularis in a long-term growth experiment. For this, a series of ten genetically identical coral nubbins of $G$. fascicularis were cultured for a period of 42 weeks at a wide range of defined flow speeds $\left(0-25 \mathrm{~cm} \mathrm{~s}^{-1}\right)$ in a controlled aquarium environment. The range of flow speeds was chosen to contain flow speeds higher than $10 \mathrm{~cm} \mathrm{~s}^{-1}$ up to the highest average flow speed that was technically feasible in our experimental setup $\left(25 \mathrm{~cm} \mathrm{~s}^{-1}\right)$. Growth was measured at regular intervals. We hypothesized that increasing waterflow rates would have a positive effect on skeletal growth.
Secondly, effect of flow on photosynthesis, respiration, and the calculated daily amount of photosynthetic carbon left for coral growth was studied in short-term experiments and was related to effects of flow on growth. We hypothesized that phototrophic metabolism and growth would be positively correlated. Thirdly, at the end of the long-term and short-term experiments, the effect of water flow on different coral biomass parameters $(\mathrm{CN}$ content, chlorophyll concentration and ash-free dry weight of coral tissue and skeletal density) was determined. Here, we hypothesized that corals cultured at higher flow regimes (i.e., higher hydrodynamic stress) would have more dense skeletons, to withstand physical damage (Schumacher and Plewka 1981; Scoffin et al. 1992; Bucher et al. 1998; Smith et al. 2007).

\section{Materials and methods}

Long-term growth experiment

\section{Study species}

Forty (40) coral nubbins (single polyp clones) of G. fascicularis were created from coral colonies that were grown at an irradiance of ca $60 \mu \mathrm{E} \mathrm{m}^{-2} \mathrm{~s}^{-1}$ (70 W HQI) in a closed-circuit coral aquaculture system in Burgers Ocean, Arnhem, The Netherlands. This 6,800 1 system consists of four 1,300 1 aquaria and two 8001 sumps, one with live rock and the other without. The circulation system cycles $18 \mathrm{~m}^{3} \mathrm{~h}^{-1}$, and the system is connected to a trickle tower, a 23.51 self-made $\mathrm{Ca}^{2+}$ reactor, and a Schuran Aquafloater AQ250 protein skimmer. Each coral nubbin was fixed to a $7 \times 7 \mathrm{~cm}$ PVC plate using a two-component epoxy (Reef Construct, Aquamedic). After a 3 weeks acclimation period, each coral nubbin was placed on one of four rectangular peg-boards in two rows of five coral nubbins.

\section{Experimental setup}

Each peg-board containing 10 coral nubbins was assigned to each of four experimental treatments: no water flow $\left( \pm 0 \mathrm{~cm} \mathrm{~s}^{-1}\right), \quad \pm 10 \mathrm{~cm} \mathrm{~s}^{-1}$ bidirectional water flow, $\pm 20 \mathrm{~cm} \mathrm{~s}^{-1}$ bidirectional water flow, and $\pm 25 \mathrm{~cm} \mathrm{~s}^{-1}$ bidirectional water flow. The actual average water-flow speeds during the long-term growth experiment were resp. $1.2 \pm 1,9.0 \pm 2.5,17.5 \pm 3.7$, and $24.5 \pm 4.4 \mathrm{SD} \mathrm{cm} \mathrm{s}^{-1}$. The different flow regimes were created using Tunze Turbelle Stream 6000 and 6100 pumps that were hung at either end of a submerged, open flowcell and adjusted to the desired flow speed (Fig. 1). Flow direction was changed every 5 min using a Tunze 7095 Multicontroller. By offering water flow in two directions, it was assumed that the effect of flow on coral physiology would not be 
Fig. 1 Side view of a submerged flow cell $(1 \times w \times h: 95 \times 30 \times$ $25 \mathrm{~cm}$ ). a Tunze pumps, $\mathbf{b}$ flow straighteners, $\mathbf{c}$ position of SENSA RC-2 electromagnetic velocity meter (Aquadata) when measuring water flow. The small black circle is the position of the sensor tip. The dashed line indicates the water level inside the coral culture system

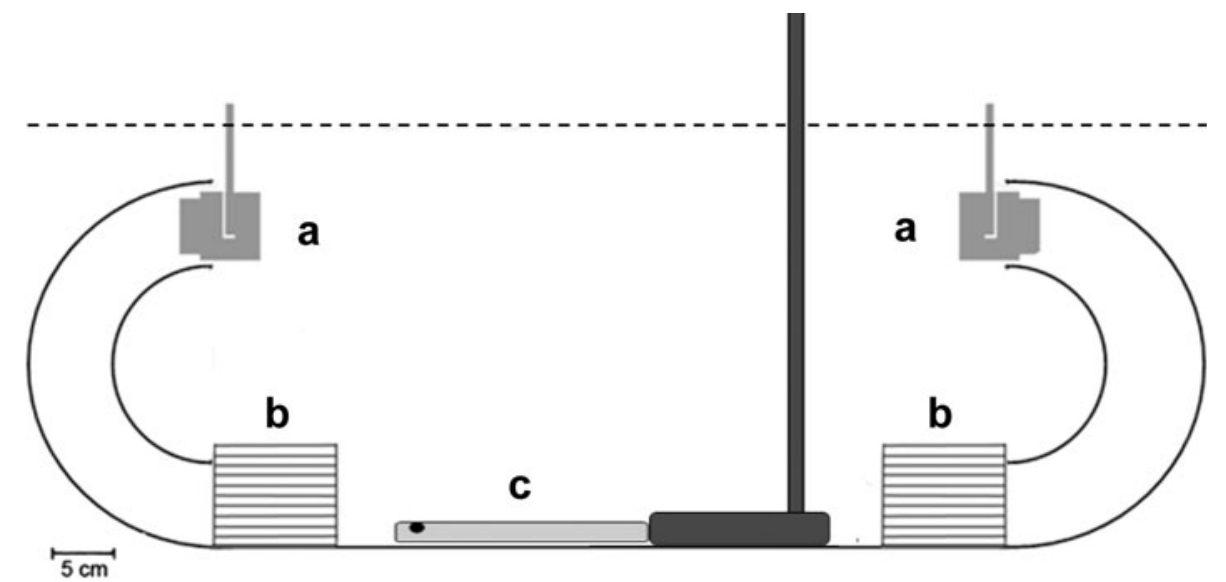

one-sided. Flow straighteners were constructed of $10-\mathrm{cm}-$ long PVC pipes with a diameter of $1 \mathrm{~cm}$ and placed downstream from the pump outlets and before the location of the corals, to create a more or less uniform flow pattern. A rectangular cell was constructed for the $0 \mathrm{~cm} \mathrm{~s}^{-1}$ flow regime. Flow speeds were measured every 4 weeks by placing a SENSA RC-2 electromagnetic velocity meter (Aquadata) in each submerged flowcell (in the absence of any corals) with its sensor tips $5 \mathrm{~cm}$ from the flow straighteners (Fig. 1), which is the location of the first coral on each PVC plate. Flow speeds were adjusted if needed.

Lighting was provided by fluorescent T8 lighting systems with 36-W Philips Tl-D90 965 color bulbs, providing an equal light distribution (see Schutter et al. 2008). Irradiance was measured using a Li-Cor 192SA quantum underwater sensor and maintained at $90 \mu \mathrm{E} \mathrm{m}^{-2} \mathrm{~s}^{-1}$. A light dark cycle of 10L:14D was applied.

Each experimental treatment was fed indirectly by daily feeding of the entire coral culture system (4-8 artemia $\mathrm{ml}^{-1}$ ) and additionally twice a week directly inside each experimental treatment (i.e., each submerged flowcell) $(5,000 \pm 800$ Artemia nauplii per treatment, yielding 15 artemia $^{-1}$ ). Artemia nauplii (Salt Lake aquafeed) were hatched on site and subsequently enriched using Rich Advanced feed for $24 \mathrm{~h}$.

Seawater was made up from Tropical Marine salt (Zoomix without bromide). Temperature was maintained at $26 \pm 2 \mathrm{SD}^{\circ} \mathrm{C}$, salinity at $34 \pm 0.3 \mathrm{SD}$, and $\mathrm{pH}$ at $8.0 \pm 0.3$ $\mathrm{SD}$. Water quality parameters were measured at regular intervals. During the experiment, alkalinity in the system was $4.0 \pm 1.0 \mathrm{SD} \mathrm{mEq}{ }^{-1}$, calcium concentration $395 \pm$ $20 \mathrm{SD} \mathrm{mg} 1^{-1}$, magnesium concentration $1,200 \pm 50 \mathrm{SD}$ $\mathrm{mg}^{-1}$, nitrate concentration $0.03 \pm 0.01 \mathrm{SD} \mathrm{mg} \mathrm{1^{-1 }}$ $\mathrm{NO}_{3}{ }^{-}$, and phosphate concentration $0.02 \pm 0.01 \mathrm{SD}$ $\mathrm{mg} \mathrm{l}^{-1} \mathrm{PO}_{4}{ }^{3-}$. Algae fouling and growth of cyanobacteria were controlled by removing any algae growing on and around the PVC plates every week.

\section{Growth parameters and analysis of growth kinetics}

Growth was measured as an increase in buoyant weight (according to Schutter et al. 2008), surface area, and polyp number of the coral nubbins. Determination of buoyant weight is a good method to measure skeletal growth, since coral tissue has a density similar to that of seawater, and therefore does not contribute significantly to the buoyant weight of the coral (Davies 1989). Surface area was measured as projected surface area. Pictures were taken perpendicular to the coral directly inside the aquarium system using a Nikon coolpix S1 $5.1 \mathrm{mp}$ digital camera in a Nikon WP-CP5 underwater housing. Surface area was determined by image analysis using Image $\mathbf{J}$ $(1.37 \mathrm{v})$ by tracing the live part of each coral colony. Since tentacle extension is variable over time, no tentacles that were extending beyond the skeleton were traced for surface area. Polyp number was counted visually. Only live polyps were counted. Newly formed polyps were only counted once they started projecting from the basal skeletal plate. All methods were non-destructive. However, since the coral colonies needed to be taken out of the aquarium for the determination of buoyant weight and polyp number, these measurements were taken only every 6 weeks for a 42-week period to reduce the amount of handling. Surface area was determined inside the experimental treatments and was therefore measured every 3 weeks for a 42 -week period.

For comparison with growth rates from a previous study, exponential growth was assumed and specific growth rates $(\mu)$ were calculated using the formula:

$\mu=\left(\operatorname{ln~BW}_{n}-\ln \mathrm{BW}_{n-1}\right) / \Delta t \quad\left[\mathrm{day}^{-1}\right]$

where $\mu$ is the specific growth rate $\left(\right.$ day $\left.^{-1}\right), \mathrm{BW}_{n}$ is buoyant weight at the end of a growth interval, $\mathrm{BW}_{n-1}$ is buoyant weight at the start of a growth interval, and $\Delta t$ is time between measurements of buoyant weight in this growth 
interval. The same was done for surface area and polyp number.

Short-term physiological experiments

\section{Respirometric flowcell}

A respirometric flowcell (1616 $\pm 5 \mathrm{ml}$ ) (Fig. 2) was designed and built at Wageningen University to study the metabolic rates of $G$. fascicularis colonies in response to different water-flow speeds. Water flow is created by two RC-280 model boat propellers $(\varnothing 3 \mathrm{~cm})$ that are driven by two separate Maxon DC motors that allow precise control of rotation speed through the EPOS_UserInterface (Version 2.31) software. The propellers are placed in such a way to create an unidirectional flow inside the flowcell. Using this setup, flow speeds from 0 to $30 \mathrm{~cm} \mathrm{~s}^{-1}$ were attained. Upstream from the coral colony, the water passes a $3-\mathrm{cm}-$ long flow straightener constructed from plastic straws ( $\varnothing 5 \mathrm{~mm}$ ) to decrease turbulence and create a more laminar flow. Behind the flow straighteners, a small coral colony was placed underneath a translucent lid made of Perspex, which allowed the passage of all wavelengths between 400 and $700 \mathrm{~nm}$. Oxygen measurements are made using a LDO probe (Luminiscent Dissolved Oxygen, Hach), which was placed downstream of the coral colonies. A built-in water jacket is connected to a TECO TR10 cooler to keep the water temperature inside the flowcell at $26 \pm 0.4^{\circ} \mathrm{C}$.

Water-flow speeds across the coral section were calibrated by tracing plastic particles $(\varnothing 1 \mathrm{~mm})$ moving in a 5-mm light beam plane created by a slide projector with a slitted cover across the lens. The beam plane was projected at a height of $\pm 3 \mathrm{~cm}$ in the flowcell, which is the average height of the coral colonies used in this study. Video recordings were made using a JVC GR-DVL digital video camera, and particle positions were traced in successive video frames (1/30 s apart) using Midas Player 2.2.0.8

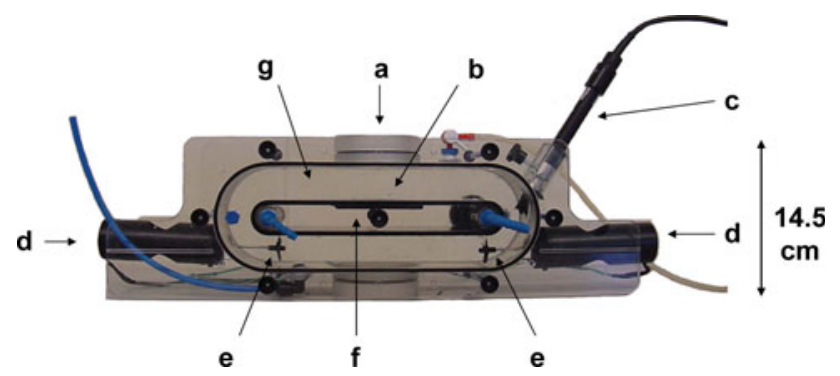

Fig. 2 Respirometric flowcell. The most important parts are indicated with an arrow and accompanying alphabetic letter. a Glass screw cap, b location of coral, c location of oxygen probe (downstream of coral), $\mathbf{d}$ site of attachment for the motor block that powers the propeller, e propeller, $\mathbf{f}$ internal water jacket that can be connected to a water bath, $\mathbf{g}$ location of flow straighteners (upstream from coral)
(Xcitex, free version). Only particles that remained in the beam plane for four or more successive frames were used, to reduce error due to particles moving diagonally across the beam plane (Sebens and Johnson 1991).

\section{Respirometric flowcell incubations}

Three corals from each experimental flow treatment were randomly chosen at the end of the long-term growth experiment and used to measure photosynthetic and respiratory rates at their corresponding flow speeds. The incubations were conducted at the end of the long-term growth experiment to reduce possible negative effects of handling on coral growth. During the execution of the short-term experiment, the experimental flow treatments in the coral culture system were maintained as before. It was not possible to get accurate oxygen readings for the corals from the $0 \mathrm{~cm} / \mathrm{s}$ flow regime using our setup.

Each coral was measured on three different days, each day starting with a control incubation in the light, three replicate 30 -min trials for photosynthesis, a control incubation in the dark and three replicate 30-min trials for respiration. At least a few hours before incubation, algae or cyanobacteria were cleaned off each coral, to prevent any anomalous contributions to photosynthesis and respiration measurements. Corals were left undisturbed as long as possible between different incubation days in order to reduce possible effects of measurement handling.

Net photosynthetic production of oxygen and respirometric consumption of oxygen was measured according to Schutter et al. (2008) and was expressed as $\mu \mathrm{mol} \mathrm{O} \mathrm{O}_{2} \min ^{-1}$ $\mathrm{cm}^{-2}$. Temperature inside the respirometric flowcell was maintained at $26 \pm 0.5 \mathrm{SD}^{\circ} \mathrm{C}$ and salinity at $34 \pm 0.1$ SD ppt.

Lighting was provided using a T5 lighting system (ATI) containing four 24-W Aquablue Spezial bulbs. Irradiance was adjusted to an irradiance of ca $90 \mu \mathrm{E} \mathrm{m}^{-2} \mathrm{~s}^{-1}$ using a Profilux II aquatic computer-controller (GHL) and measured using a Li-Cor 192SA quantum underwater sensor. This irradiance corresponded to the irradiance experienced in the growth experiment.

Surface area, volume, and buoyant weight of the experimental corals were determined weekly during this experimental period. Surface area was determined to normalize the respirometric data. The volume of the coral was determined using the water displacement technique to correct flowcell volume for the space taken in by the coral. Buoyant weight was determined to monitor the growth during this experimental period. Besides that, buoyant weight of all corals from the growth experiment was determined before and after the respirometric flowcell incubations, to test whether the extra experimental handling had an effect on growth rates of these corals. 
Scope for growth

Scope for growth, based on solely phototrophic feeding, was determined by calculating the daily amount of carbon per $\mathrm{cm}^{2}$ of coral that is left after satisfying respiratory needs (after Anthony and Fabricius 2000). Scope for growth indicates whether corals can satisfy their daily respiratory needs using photosynthetic products translocated by their zooxanthellae only (i.e., are self-supporting with respect to carbon, scope for growth $>0$ ) and how much (phototrophic) carbon would be left for growth or other processes.

To be able to calculate scope for growth, net photosynthetic rates and dark respiratory rates were converted to carbon equivalents, using a 1:1 molar ratio to convert oxygen evolution measurements into carbon equivalents. Since we do not know the exact composition of substances that are produced during photosynthesis and that are respired during respiration, no further corrections were applied using metabolic quotients (Gattuso and Jaubert 1990).

Scope for growth was calculated using the following equation:

$\mathrm{SfG}=\left(P_{\mathrm{c}} \times 10\right)-\left(R_{\mathrm{c}} \times 14\right)$

where SfG is scope for growth based on phototrophic feeding expressed in $\mu \mathrm{mol} \mathrm{C} \mathrm{h}{ }^{-1} \mathrm{~cm}^{-2}$, and $P_{\mathrm{c}}$ and $R_{\mathrm{c}}$ are photosynthetic and respiratory rates expressed in $\mu \mathrm{mol} \mathrm{C} \mathrm{h} \mathrm{h}^{-1} \mathrm{~cm}^{-2}$. Calculations were based on a lightdark period of 10L:14D.

\section{Coral biomass parameters}

At the end of all respirometric flowcell incubations, buoyant weight, surface area, and volume were once more determined for all corals. An estimate of the skeletal (bulk) density of the coral skeleton was calculated by dividing the buoyant weight $(\mathrm{g})$ of the coral skeleton by the total enclosed volume $(\mathrm{ml})$ of the coral skeleton (Bucher et al. 1998). Then, all corals were used for subsequent analysis of their tissue.

Corals were snap-fixed in $10 \%$ formaldehyde in $0.22 \mu \mathrm{m}$ filtered seawater (FSW) (34 ppt) and then placed in 250-300-ml $\mathrm{Ca}^{2+}-\mathrm{Mg}^{2+}$-free artificial seawater (ASW) with ethylenediaminetetraacetic acid (EDTA). This solution was prepared according to Rinkevich et al. (2005). Coral tissue was splashed off after 30-min ultra-sonification by using sharp water jets coming from small pipettes. Cell suspensions were collected, diluted with $0.22-\mu \mathrm{m}$ FSW, and centrifuged twice for $10 \mathrm{~min}$ at $3^{\circ} \mathrm{C}$ at $4,000 \mathrm{rpm}$, after which total volume was determined.

Each tissue sample was homogenized using a LABOCAT X1030, after which subsamples were taken for analyses of chlorophyll, ash-free dry weight, and $\mathrm{CN}$ content.
Chlorophyll was extracted by adding $9 \mathrm{ml} 100 \%$ acetone to $900-1,000-\mu l$ tissue homogenate and storing it at $-20^{\circ} \mathrm{C}$ overnight. Absorbance of the extract was measured in triplicate using a Beckman Coulter DU 530 Spectrophotometer at 750, 664, and $630 \mathrm{~nm}$. Ninety percentage of acetone was used as a blank. The concentrations of chlorophyll $a$ and chlorophyll $c_{2}$ were computed according to the equations given by Jeffrey and Humphrey (1975) for dinoflagellates.

A duplicate of approximately 4-7-ml tissue homogenate of each coral was dried at $103^{\circ} \mathrm{C}$ until constant weight and then burnt at $550^{\circ} \mathrm{C}$ until constant weight. Ash-free dry weight was calculated by subtracting ash weight from dry weight. Due to the small amount of tissue of the corals from the zero flow treatment, the tissue sample used for chlorophyll analysis was recovered for analysis of ash-free dry weight by evaporating the acetone at $60^{\circ} \mathrm{C}$ inside a fume hood and resuspending the pellet in a final volume of 1-ml 0.22 FSW (34 ppt).

$\mathrm{CN}$ analysis was done using an EA $1108 \mathrm{CHN}-\mathrm{O}$ from Fisons Instruments. Approximately $10 \mu \mathrm{l}$ of wet tissue suspension $(\sim 10-15 \mu \mathrm{g}$ in dry weight) was used for each measurement, measuring each coral in triplicate. Atropine was used as a standard.

Data analysis

Statistical analyses were made using the SAS 9.1. All data were analyzed using a one-way analysis of variance (ANOVA) followed by the Tukey's HSD post hoc test. To test whether our data satisfied the assumptions for ANOVA testing, the error terms of the ANOVA analyses were tested for homogeneity of variances $(P>0.05)$ and normality $(P>0.05)$ using, respectively, the Levene's test and the Shapiro-Wilk test. Only the data for photosynthesis, respiration, and scope for growth satisfied the assumptions for ANOVA. Data that did not satisfy the assumptions for ANOVA were subsequently tested using the non-parametric Kruskal-Wallis test to detect statistical differences between treatments. This was followed by pair wise comparisons using the Mann-Whitney $U$ test. Results were considered statistically significant when $P$-values were below 0.05 .

\section{Results}

Growth parameters

\section{Buoyant weight}

All corals grew in buoyant weight during the experiment $(P<0.001$, Fig. 3). The first significant differences in buoyant weight between flow regimes became apparent 


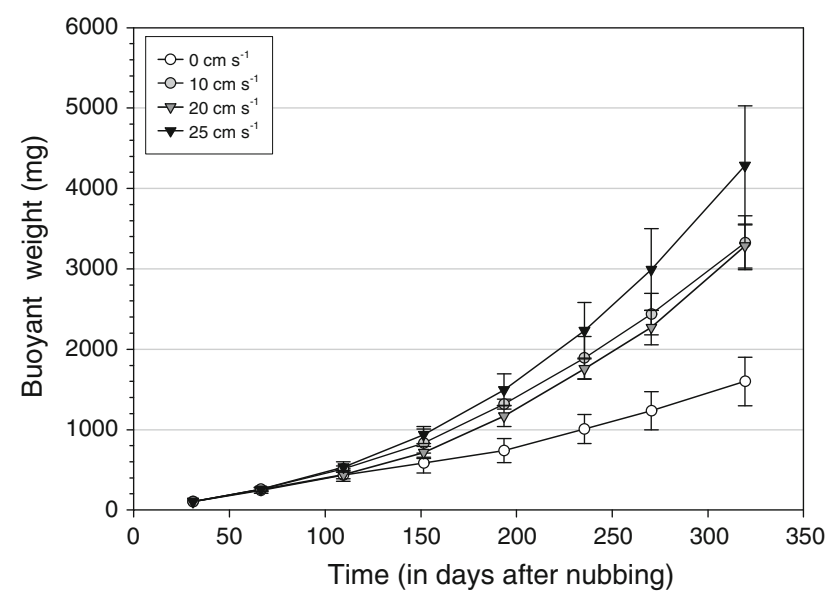

Fig. 3 The effect of flow regime on buoyant weight increase during the experimental period. Values are mean $\pm \mathrm{SD}, N=10$

after 12 weeks (110 days after nubbing) $(P=0.0005)$. At the end of the growth experiment (week 42), the corals in the $0 \mathrm{~cm} \mathrm{~s}^{-1}$ flow treatment had a significant lower buoyant weight compared with the corals in the 10,20, and $25 \mathrm{~cm} \mathrm{~s}^{-1}$ flow treatment $(P=0.0002)$, while the corals in the $25 \mathrm{~cm} \mathrm{~s}^{-1}$ flow treatment had a significantly higher buoyant weight compared with the corals in the 0,10 , and $20 \mathrm{~cm} \mathrm{~s}^{-1}$ flow treatment $(P<0.0005)$. No difference was detected between the 10 and $20 \mathrm{~cm} \mathrm{~s}^{-1}$ corals $(P=0.82)$. The corals in the $0 \mathrm{~cm} \mathrm{~s}^{-1}$ flow treatment appeared unhealthy, their tissue was pale and showed regression from time to time.

\section{Surface area}

The increase in surface area during the experiment (Fig. 4), gave a similar result as the increase in buoyant weight (Fig. 3), except that differences in surface area between treatments became apparent only at week 15 (135 days) $(P<0.0001)$.

Growth in surface area was found to be not as continuous as in buoyant weight. When growing, G. fascicularis appears to first create a layer of tissue around the coral (in a circular fashion), in which ultimately some polyps will be formed. Thus, this type of growth occurs in "bursts." Skeletal growth, on the other hand, is an ongoing process also occurring in the central part of the colony. Growth in surface area is also much more hindered by algal competition than growth as buoyant weight (visual observation).

At the end of the growth experiment (week 42, 320 days), the relative differences in growth as surface area between flow treatments were similar to the relative differences in growth as buoyant weight: $0 \mathrm{~cm} \mathrm{~s}^{-1}$ flow treatment had a significant lower surface area compared with the corals in the 10,20 , and $25 \mathrm{~cm} \mathrm{~s}^{-1}$ flow treatment $(P=0.0002)$, while the corals in the $25 \mathrm{~cm} \mathrm{~s}^{-1}$ flow

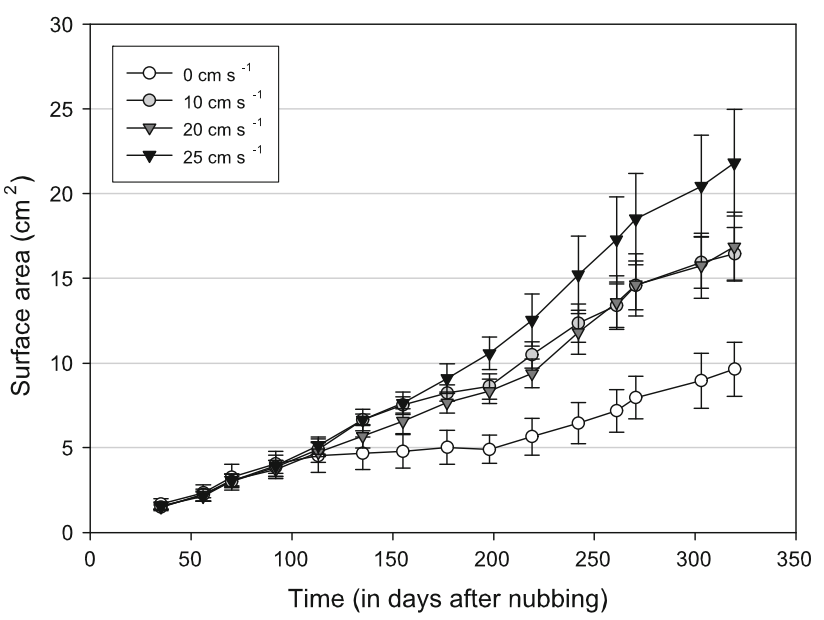

Fig. 4 The effect of flow regime on surface area increase during the experimental period. Values are mean $\pm \mathrm{SD}, N=10$

treatment had a significantly higher surface area compared with the corals in the 0,10 , and $20 \mathrm{~cm} \mathrm{~s}^{-1}$ flow treatment $(P \leq 0.0012)$. No difference was detected between the 10 and $20 \mathrm{~cm} \mathrm{~s}^{-1}$ corals $(P=0.8206)$.

\section{Polyp number}

The increase in polyp number during the experiment (Fig. 5) gave a slightly different result than the increase in buoyant weight (Fig. 3) and surface area (Fig. 4).

Just as with buoyant weight, the first significant differences in polyp number between flow regimes became apparent at week 12 (110 days after nubbing $)(P<0.0001)$. However, at the end of the growth experiment (week 42), polyp numbers had significantly increased with each flow regime. The $0 \mathrm{~cm} \mathrm{~s}^{-1}$ flow treatment had a significant lower polyp number compared to the corals in the 10,20 , and $25 \mathrm{~cm} \mathrm{~s}^{-1}$ flow treatment $(P<0.0003)$. The $10 \mathrm{~cm} \mathrm{~s}^{-1}$ flow treatment had a significant lower polyp number compared to the corals in the 20 and $25 \mathrm{~cm} \mathrm{~s}^{-1}$ flow treatment $(P<0.05)$, and the $20 \mathrm{~cm} \mathrm{~s}^{-1}$ flow treatment had a significantly lower polyp number than the corals in the $25 \mathrm{~cm} \mathrm{~s}^{-1}$ flow treatment $(P<0.005)$.

\section{Growth kinetics}

Specific growth rates were calculated per measurement interval using the buoyant weight data (Fig. 6). It was seen that the specific growth rate decreased with time, implying that the growth of $G$. fascicularis was not exponential. Within measurement intervals, the growth of the $0 \mathrm{~cm} \mathrm{~s}^{-1}$ nubbins was consistently lower, with exception of the growth interval between week 6 and 12 where the specific growth rate of the $20 \mathrm{~cm} \mathrm{~s}^{-1}$ nubbins was also decreased. The differences in specific growth rates between the corals in the 10, 20, and $25 \mathrm{~cm} \mathrm{~s}^{-1}$ flow treatment were not consistent. 


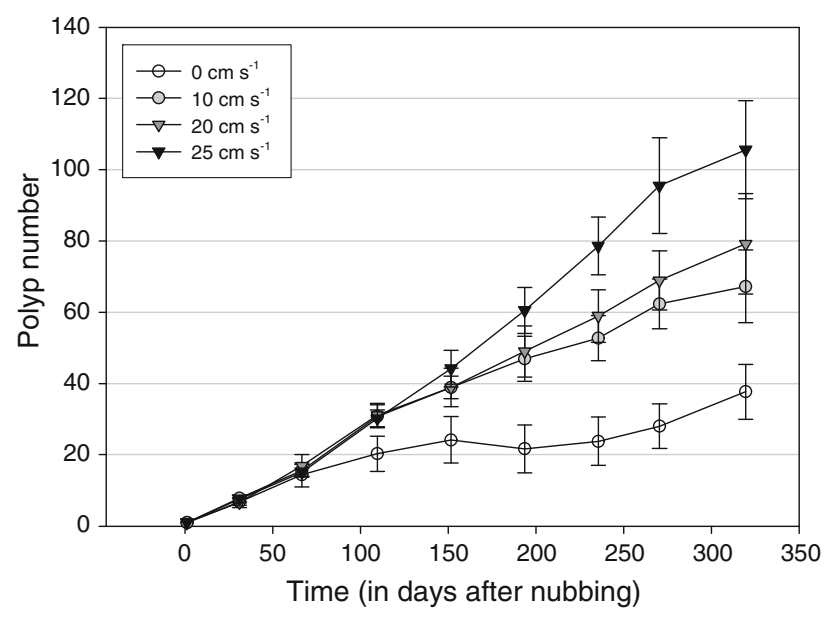

Fig. 5 The effect of flow regime on polyp number increase during the experimental period. Values are mean $\pm \mathrm{SD}, N=10$

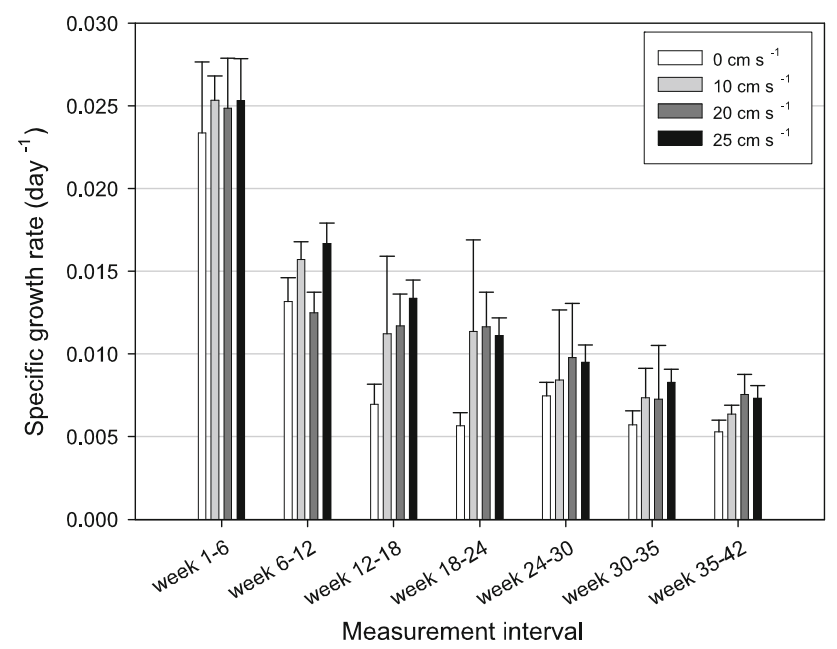

Fig. 6 Specific growth rates $\left(\right.$ day $\left.^{-1}\right)$ based on coral buoyant weight and calculated for each measurement interval. Values are mean $\pm \mathrm{SD}, N=10$

On average, over the entire experimental period (week 1 to week 42), specific growth rate was $0.0094 \pm 0.0007 \mathrm{day}^{-1}$ in the $0 \mathrm{~cm} \mathrm{~s}^{-1}$ flow treatment, $0.0119 \pm 0.0004$ day $^{-1}$ in the $10 \mathrm{~cm} \mathrm{~s}^{-1}$ flow treatment, $0.0119 \pm 0.0003 \mathrm{day}^{-1}$ in the $20 \mathrm{~cm} \mathrm{~s}^{-1}$ flow treatment, and $0.0128 \pm 0.0006$ day $^{-1}$ in the $25 \mathrm{~cm} \mathrm{~s}^{-1}$ flow treatment.

\section{Respirometric measurements}

\section{Net photosynthesis and dark respiration}

Net photosynthesis decreased with flow speed. A significant difference was detected between $10(11.7 \pm 1.8 \mathrm{nmol}$ $\left.\mathrm{O}_{2} \min ^{-1} \mathrm{~cm}^{-2}\right)$ and $25 \mathrm{~cm} \mathrm{~s}^{-1} \quad(8.2 \pm 0.2 \mathrm{nmol} \mathrm{O} 2$ $\left.\min ^{-1} \mathrm{~cm}^{-2}\right)(P=0.03)$. However, no significant differences were detected between 10 and $20 \mathrm{~cm} \mathrm{~s}^{-1}$ (10.4 \pm

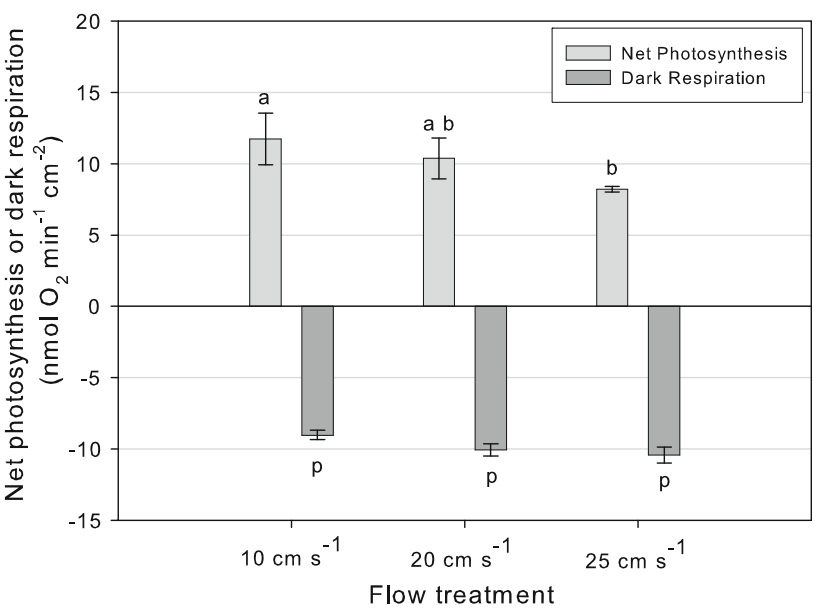

Fig. 7 The effect of water-flow speed on net photosynthesis and dark respiration. Values are mean $\pm \mathrm{SD}, N=3$. Means lacking a common superscript differ significantly $(P<0.05)$

$\left.1.4 \mathrm{nmol} \mathrm{O}_{2} \min ^{-1} \mathrm{~cm}^{-2}\right)(P=0.71)$ and $20 \mathrm{~cm} \mathrm{~s}^{-1} 25 \mathrm{~cm}$ $\mathrm{s}^{-1}(P=0.08)$ (Fig. 7).

Dark respiration was not significantly different between either $10 \mathrm{~cm} \mathrm{~s}^{-1}\left(-9.0 \pm 0.3 \mathrm{nmol} \mathrm{O} \mathrm{min}^{-1} \mathrm{~cm}^{-2}\right)$ and $20 \mathrm{~cm} \mathrm{~s}^{-1}\left(-10.0 \pm 0.4 \mathrm{nmol} \mathrm{O} \mathrm{min}^{-1} \mathrm{~cm}^{-2}\right)(P=0.35)$ or 10 and $25 \mathrm{~cm} \mathrm{~s}^{-1}\left(-10.4 \pm 0.6 \mathrm{nmol} \mathrm{O} \mathrm{min}^{-1} \mathrm{~cm}^{-2}\right)$ $(P=0.08)$ or 20 and $25 \mathrm{~cm} \mathrm{~s}^{-1}(P=0.53)$ (Fig. 7).

During these short-term incubation experiments, the skeletal growth rate (in day $^{-1}$ ) of the experimental corals $(n=3)$ in each flow treatment was not significantly different $(P>0.14)$ from the corals that remained untouched in the flow experiment $(n=7)$. Thus, during this time period, no significant effect of handling on skeletal growth rate was detected.

\section{Scope for growth}

Scope for growth based on phototrophic carbon decreased with flow speed. Scope for growth was $-0.54 \pm 0.98$ $\mathrm{SD} \mu \mathrm{mol} \mathrm{C} \mathrm{cm}{ }^{-2} \mathrm{day}^{-1}$ for $10 \mathrm{~cm} \mathrm{~s}^{-1},-2.22 \pm 0.81 \mathrm{SD}$ $\mu \mathrm{mol} \mathrm{C} \mathrm{cm}{ }^{-2}$ day $^{-1}$ for $20 \mathrm{~cm} \mathrm{~s}^{-1}$, and $-3.84 \pm 0.35$ $\mathrm{SD} \mu \mathrm{mol} \mathrm{C} \mathrm{cm} \mathrm{cm}^{-2}$ for $25 \mathrm{~cm} \mathrm{~s}^{-1}$ (Fig. 8). The amount of carbon per $\mathrm{cm}^{2}$ left for other processes decreased with increasing flow rate. Scope for growth was significantly lower in the $25 \mathrm{~cm} \mathrm{~s}^{-1}$ flow treatment compared with the $10 \mathrm{~cm} \mathrm{~s}^{-1}$ flow treatment $(P=0.004)$. No significant difference was found between 10 and $20 \mathrm{~cm} \mathrm{~s}^{-1}(P=0.08)$ and 20 and $25 \mathrm{~cm} \mathrm{~s}^{-1}(P=0.09)$.

\section{Coral biomass parameters}

Coral biomass parameters were determined after the ending of the short-term incubation experiments. Since the health of corals in the $0 \mathrm{~cm} \mathrm{~s}^{-1}$ became more and more impaired after the 42-week growth experiment, the biomass 


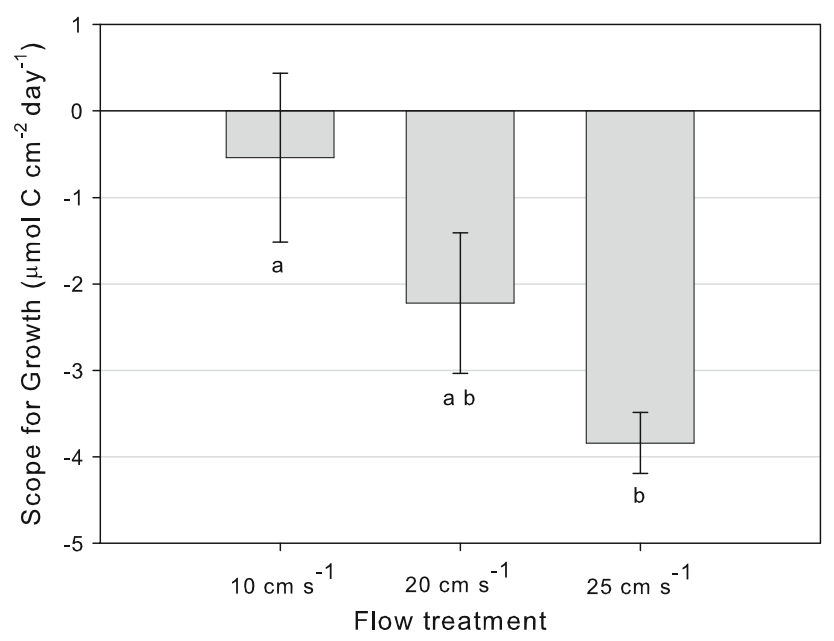

Fig. 8 Influence of flow speed on the daily amount of carbon left for growth $\left(\mu \mathrm{mol} \mathrm{C} \mathrm{cm}{ }^{-2}\right)$. Values are mean $\pm \mathrm{SD}, N=3,3$ measurements averaged per coral. Means lacking a common superscript differ significantly $(P<0.05)$

parameters measured of the $0 \mathrm{~cm} \mathrm{~s}^{-1}$ corals do not necessarily reflect the status of these corals during the growth experiment. The health of the corals in the other treatments was not impaired, and therefore their biomass parameters are assumed to be representative of the status of the corals during the entire experiment.

\section{Skeletal density}

A proxy of skeletal density was calculated by dividing buoyant weight of each coral $(\mathrm{g})$ by its volume $(\mathrm{ml})$, after subtracting weight and volume of their PVC plates. This measure of skeletal density was $0.18 \pm 0.03 \mathrm{~g} \mathrm{ml}^{-1}$ for the corals in the $0 \mathrm{~cm} \mathrm{~s}^{-1}$ treatment, $0.67 \pm 0.06 \mathrm{~g} \mathrm{ml}^{-1}$ for $10 \mathrm{~cm} \mathrm{~s}^{-1}, \quad 0.79 \pm 0.11 \mathrm{~g} \mathrm{ml}^{-1}$ for $20 \mathrm{~cm} \mathrm{~s}^{-1}$, and $0.75 \pm 0.11 \mathrm{~g} \mathrm{ml}^{-1}$ for $25 \mathrm{~cm} \mathrm{~s}^{-1}$. The corals in the zero flow treatment had a significantly lower skeletal density than the others $(P<0.005)$, while the skeletal density of the corals in the other flow treatments was not significantly different from each other $(P>0.08)$.

\section{Coral tissue parameters}

Ash-free dry weight of coral tissue per surface area was significantly lowest in the $0 \mathrm{~cm} \mathrm{~s}^{-1}$ treatment $(3.6 \pm$ $\left.1.5 \mu \mathrm{g} \mathrm{cm}^{-2}, P<0.008\right)$, while it was significantly highest for the corals in the $10 \mathrm{~cm} \mathrm{~s}^{-1}$ treatment $(8.4 \pm 1.9$ $\left.\mu \mathrm{g} \mathrm{cm}{ }^{-2}, P<0.03\right)$. No significant difference was found between the corals in $20 \mathrm{~cm} \mathrm{~s}^{-1}\left(5.5 \pm 1.1 \mu \mathrm{g} \mathrm{cm}^{-2}\right)$ and $25 \mathrm{~cm} \mathrm{~s}^{-1}\left(5.4 \pm 1.3 \mu \mathrm{g} \mathrm{cm}^{-2}\right)(P=0.74)$ (Fig. 9).

The percentage of carbon in coral tissue $(41.4 \pm 7.6 \% \mathrm{C}$, calculated as mg C per mg ash-free dry weight of tissue) was not significantly different between treatments $(P>0.12)$. The percentage nitrogen in coral

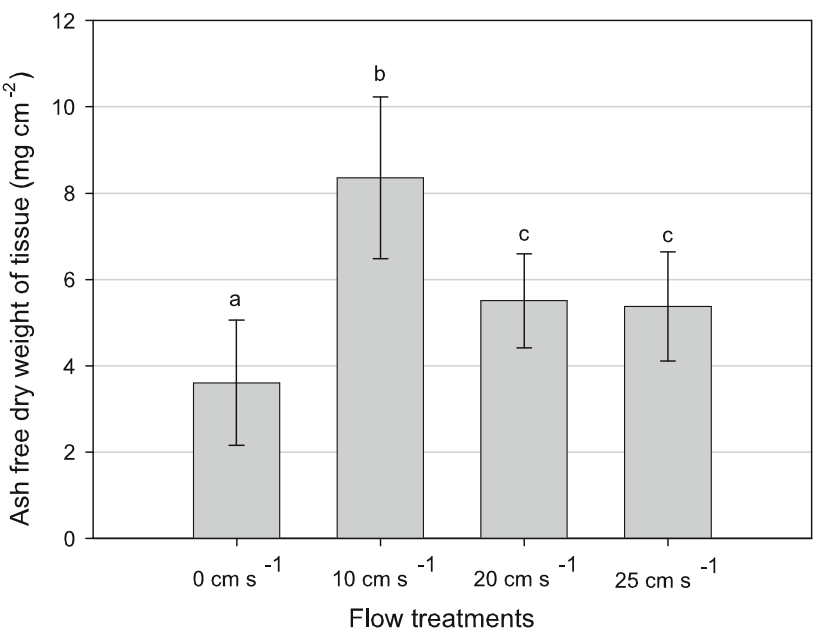

Fig. 9 The effect of flow regime on the ash-free dry weight of coral tissue per surface area of coral $\left(\mathrm{mg} \mathrm{cm}^{-2}\right)$. Values are mean $\pm \mathrm{SD}$, $N=10$ for 0,20 , and $25 \mathrm{~cm} \mathrm{~s}^{-1}, N=5$ for $10 \mathrm{~cm} \mathrm{~s}^{-1}$. Means lacking a common superscript differ significantly $(P<0.05)$

tissue, however, showed small, but significant differences between $0(7.41 \pm 0.68)$ and $20 \mathrm{~cm} \mathrm{~s}^{-1}(5.99 \pm 0.68)$ $(P=0.015)$ and between 0 and $25 \mathrm{~cm} \mathrm{~s}^{-1}(6.03 \pm 0.35)$ $(P=0.007)$, with a higher percentage nitrogen in the tissue of the $0 \mathrm{~cm} \mathrm{~s}^{-1}$ corals. The $\mathrm{C}: \mathrm{N}$ ratio increased slightly with flow speed: $5.65 \pm 1.23$ for $0 \mathrm{~cm} \mathrm{~s}^{-1}, 6.07 \pm 0.90$ for $10 \mathrm{~cm} \mathrm{~s}^{-1}, \quad 6.56 \pm 1.17$ for $20 \mathrm{~cm} \mathrm{~s}^{-1}$, and $7.18 \pm 1.21$ for $25 \mathrm{~cm} \mathrm{~s}^{-1}$. The C:N ratio of coral tissue of corals maintained at $25 \mathrm{~cm} \mathrm{~s}^{-1}$ was significantly higher than that of corals maintained at $0 \mathrm{~cm} \mathrm{~s}^{-1}(P=0.022)$.

The amount of chlorophyll $a(\mathrm{Chl} \mathrm{A})$ and chlorophyll $c_{2}$ $\left(\mathrm{Chl} \mathrm{C}_{2}\right)$ per coral surface area was significantly lower for the corals in the $0 \mathrm{~cm} \mathrm{~s}^{-1}$ flow treatment $(1.0 \pm 0.3$ $\mu \mathrm{g} \mathrm{Chl} \mathrm{A} \mathrm{cm}{ }^{-2}$ and $0.6 \pm 0.2 \mu \mathrm{g} \mathrm{Chl} \mathrm{C}_{2} \mathrm{~cm}^{-2}$ ) compared with the corals in the $10 \mathrm{~cm} \mathrm{~s}^{-1}$ flow treatment $\left(3.8 \pm 1.5 \mu \mathrm{g} \mathrm{Chl} \mathrm{A} \mathrm{cm}{ }^{-2}\right.$ and $\left.2.7 \pm 1.1 \mu \mathrm{g} \mathrm{Chl} \mathrm{C}_{2} \mathrm{~cm}^{-2}\right)$ and $25 \mathrm{~cm} \mathrm{~s}^{-1}$ flow treatment $\left(4.1 \pm 0.6 \mu \mathrm{g} \mathrm{Chl} \mathrm{A} \mathrm{cm}{ }^{-2}\right.$ and $\left.2.0 \pm 0.5 \mu \mathrm{g} \mathrm{Chl} \mathrm{C}_{2} \mathrm{~cm}^{-2}\right)(P<0.005)$. No significant difference was detected between 10 and $25 \mathrm{~cm} \mathrm{~s}^{-1}$ $(P=0.48)$. The samples of the corals in the $20 \mathrm{~cm} \mathrm{~s}^{-1}$ were lost. Since the values for $\mathrm{OD}_{664}$ (i.e., the extinction coefficient at $664 \mathrm{~nm}$, indicative of the presence and amount of Chlorophyll $a$ ) of the corals from the $0 \mathrm{~cm} \mathrm{~s}^{-1}$ flow treatment were frequently below the detection limit, the absolute values should be interpreted with caution.

\section{Discussion}

Water flow and growth

Skeletal growth of G. fascicularis increased with time in all flow treatments. Since differences in growth between treatments only started to become apparent at week 12, 
growth experiments using G. fascicularis nubbins should last at least for 12 weeks. This study demonstrated the importance of water flow to the growth of the scleractinian coral G. fascicularis. Absence of flow resulted in significant lower specific growth rates. An increase in growth was found between 0 and $10 \mathrm{~cm} \mathrm{~s}^{-1}$, which is in agreement with the findings of Jokiel (1978) in the range of 2$15 \mathrm{~cm} \mathrm{~s}^{-1}$ for Pocillopora meandrina and Pocillopora damicornis. However, no significant difference in growth was found between the 10 and $20 \mathrm{~cm} \mathrm{~s}^{-1}$ flow treatments, while the corals in the $25 \mathrm{~cm} \mathrm{~s}^{-1}$ flow treatment had a significant higher skeletal growth than the corals in the other flow treatments. The same trend was found for surface area, while polyp number was significantly increased with increasing flow. Surface area and polyp number are, however, more an expression of morphology than of clearcut skeletal growth.

Specific growth rate of $G$. fascicularis decreased with time, as observed before by Schutter et al. (2008), and fell within the range of specific growth rates to be expected for G. fascicularis at an irradiance of $90 \mu \mathrm{E} \mathrm{m}^{-2} \mathrm{~s}^{-1}$ $\left( \pm 0.012\right.$ day $^{-1}$, Schutter et al. 2008). The decline in specific growth rate during the experiment was in part a consequence of the exponential growth model. It is expected that other growth models, such as the surfacerelated growth model of half a sphere (Sipkema et al. 2006), will better describe the growth of a mound-shaped coral such as $G$. fascicularis. Although the differences in specific growth rates between flow treatments were not consistent between measurement intervals (Fig. 6), the specific growth rate calculated over the entire experimental period showed the same trend as for the growth parameters.

Water flow and phototrophic metabolism

First, it can be argued that each physiological measurement is just a random indication of the metabolic rate at the time of measurement. However, by measuring the metabolic rate of each coral at various times at different days, this potential artifact is reduced. Second, it can be argued that measurements cannot be extrapolated because of differences in colony size. However, a strong linear correlation is found between metabolic rate $\left(\mathrm{mg} \mathrm{O}_{2}\right.$ per min) and surface area $\left(\mathrm{cm}^{2}\right)$ (Adj $R^{2}=0.65, P<0.01$ for photosynthesis, adj $R^{2}=0.91, P<0.01$ for respiration) over a size range of $5-50 \mathrm{~cm}^{2}$, indicating that the measured metabolic rates are representative for a large range of coral sizes.

\section{Photosynthesis}

Reduction in the diffusive boundary layer thickness with increasing water flow did not result in increased net photosynthetic rates. In contrast, the net photosynthetic rate was not significantly different between $10 \mathrm{~cm} \mathrm{~s}^{-1}$ and $20 \mathrm{~cm} \mathrm{~s}^{-1}$ and between 20 and $25 \mathrm{~cm} \mathrm{~s}^{-1}$. However, net photosynthetic rate at $25 \mathrm{~cm} \mathrm{~s}^{-1}$ was significantly lower compared with $10 \mathrm{~cm} \mathrm{~s}^{-1}$. In this study, net photosynthetic rates were thus not positively correlated with growth, in contrast to Schutter et al. (2008). Obviously, photosynthates are not effectively channeled into skeletal growth and possibly allocated to different processes than skeletal growth. Our results are in line with Sebens et al. (2003), however, who found no differences in rate of net photosynthesis between 2, 5, 8, and $10 \mathrm{~cm} \mathrm{~s}^{-1}$ for Agaricia tenuifolia. However, Lesser et al. (1994) did find positive effects of increasing flow on net photosynthesis of Pocillopora damicornis (mean flow: $0.2,3.8$, and $7.2 \mathrm{~cm} \mathrm{~s}^{-1}$ ). The decline we found in net photosynthesis at flow rates higher than $10 \mathrm{~cm} \mathrm{~s}^{-1}$ cannot be verified with other data from the literature, since, to the best of our knowledge, no data in literature are available for comparison. At low irradiances, such as used in this study, water flow may have a smaller effect on photosynthesis, since the need for inorganic carbon supply and/or removal of oxygen to optimize photosynthesis at low irradiance levels is not as demanding as at high irradiance levels (Nakamura et al. 2005; Finelli et al. 2006; Smith and Birkeland 2007). Water flow did not have an effect on chlorophyll $a$ and chlorophyll $c_{2}$ content per surface area, which is in agreement with the findings of Stambler et al. (1991) and Lesser et al. (1994) for Pocillopora damicornis and of Rex et al. (1995) for Porites cylindrica. Clearly, irradiance has a dominant effect on photosynthesis and chlorophyll content, while water-flow rates can only modulate uptake and release rates of substances needed for photosynthesis.

\section{Respiration}

Reduction in the diffusive boundary layer thickness with increasing water flow did not result in significantly increased respiratory rates. Sebens et al. (2003) reported an increase in dark respiration with flow speed for Agaricia tenuifolia between 2 and $10 \mathrm{~cm} \mathrm{~s}^{-1}$. However, our data cannot be compared with data that have been collected at flow speeds above $10 \mathrm{~cm} \mathrm{~s}^{-1}$, since, to the best of our knowledge, such data have not been reported.

Respiration increases the availability of metabolic $\mathrm{CO}_{2}$ that can be used as a source of carbon for calcification (70\% of DIC for calcification comes from metabolic $\mathrm{CO}_{2}$ : Furla et al. 2000) and generates energy that can be used for calcification. Therefore, respiration could potentially be limiting for growth.

The decreased growth of the corals in the $0 \mathrm{~cm} \mathrm{~s}^{-1}$ flow treatment compared to the other flow treatments could possibly be the result of a limited supply of oxygen and consequently a reduced dark respiratory rate, which could 
have resulted in a reduced availability of metabolic $\mathrm{CO}_{2}$. Nevertheless, the difference in growth between 20 and $25 \mathrm{~cm} \mathrm{~s}^{-1}$ cannot be explained by dark respiratory rates, since this difference was not significantly different. Respiratory rates during the day (light respiration) will probably be independent of flow-related mass transfer, since oxygen used for respiration is not limiting due to photosynthetic production of oxygen in the light.

\section{Scope for growth}

Scope for growth based on phototrophic feeding (i.e., daily amount of photosynthetic carbon that is left for other processes after satisfying respiratory needs) was negatively correlated with growth rate, indicating that phototrophic carbon was not instrumental in supporting higher skeletal growth rates.

Since the average net photosynthetic rate in this study was $50 \%$ lower than what we would expect, based on previous photosynthesis-irradiance curves of G. fascicularis measured under similar conditions (Schutter et al. 2008), and average respiratory rate was threefold higher, absolute values should be interpreted with caution. Differences between respirometric values could possibly be the result of the short-term nature of the measurement of a photosynthesis-irradiance curve and the influence of the growth irradiance on the result. A photosynthesis-irradiance curve provides information about the potential to acclimate to irradiance within a short time, while in the long run, the photosynthetic rate at a certain irradiance intensity might be different because of long-term adaptations of the coral's physiology. Nevertheless, these data do provide a qualitative indication of the effect of flow on photosynthesis, respiration, and scope for growth.

While the corals in the $10 \mathrm{~cm} \mathrm{~s}^{-1}$ flow treatment had the highest scope for growth, this did not seem instrumental in supporting higher skeletal growth rates. It might be possible that this carbon was not allocated to skeletal growth but to tissue growth, since ash-free dry weight of the coral tissue was significantly higher. Since the average C:N ratio of tissue of the $10 \mathrm{~cm} \mathrm{~s}^{-1}$ corals was not significantly different from the other flow treatments, no difference in the composition of the tissue is expected. This excludes the possibility that the $10 \mathrm{~cm} \mathrm{~s}^{-1}$ corals had stored more (carbon-rich) storage compounds (Glynn et al. 1985; Harland et al. 1992; Anthony et al. 2002), which would occur if the amount of translocated carbon-rich photosynthetic products exceeds that what is necessary to keep pace with skeletal growth (Anthony et al. 2002). The tissue mass thus seems normal. The average $\mathrm{C}: \mathrm{N}$ ratio of coral tissue $(6.37 \pm 1.26)$ found in this study (with exception of $0 \mathrm{~cm} \mathrm{~s}^{-1}$ corals) is in line with values reported in literature for Montastrea annularis (7.5, Szmant and Gassman 1990) and Pocillopora damicornis (8-10, Lesser et al. 1994) and suggests total nutrient sufficiency.

Water flow and energy allocation

The increased growth at $25 \mathrm{~cm} \mathrm{~s}^{-1}$ compared with growth at 10 and $20 \mathrm{~cm} \mathrm{~s}^{-1}$ cannot be explained by the availability of photosynthetic carbon. Alternative potential explanations are that: (1) corals at high flow have better access to other sources of carbon (e.g., artemia, DOC) resulting in an increase in scope for growth (based on both sources of carbon) with increasing water-flow speed (Atkinson and Bilger 1992), and/or (2) corals at high flow have an increased supply of inorganic carbon $\left(\mathrm{HCO}_{3}{ }^{-}\right)$which is required for calcification, and/or (3) different allocation processes played a role and therefore energy was allocated among different biological functions, e.g., between skeletal growth, tissue growth, and competition.

Tissue mass of the corals in the 20 and $25 \mathrm{~cm} \mathrm{~s}^{-1}$ flow treatment was significantly lower compared with $10 \mathrm{~cm} \mathrm{~s}^{-1}$. The decreased availability of photosynthetic carbon with flow does not seem to explain the decreased tissue mass, since a similar amount of carbon was allocated to both the 20 and $25 \mathrm{~cm} \mathrm{~s}^{-1}$ corals. Moreover, despite a lower availability of photosynthetic carbon, a significant amount of carbon was allocated to skeletal growth in the case of the $25 \mathrm{~cm} \mathrm{~s}^{-1}$ corals. The corals in the $25 \mathrm{~cm} \mathrm{~s}^{-1}$ treatment must therefore either have had more access to other sources of carbon or the available carbon was allocated to different processes. Since the corals in the $25 \mathrm{~cm} \mathrm{~s}^{-1}$ flow treatment experienced the lowest competition with fouling algae and cyanobacteria (personal observation), it is possible that they were able to allocate more energy to skeletal growth than to defense or repair mechanisms against competing algae or cyanobacteria (McCook et al. 2001; Kuffner et al. 2006). The inconsistent differences in specific growth rates between growth intervals among the corals in the 10,20 , and $25 \mathrm{~cm} \mathrm{~s}^{-1}$ treatment also confirm this differential energy allocation. Although the corals in the lower flow treatments (10 and $20 \mathrm{~cm} \mathrm{~s}^{-1}$ ) were able to express a similar growth potential as the corals in the $25 \mathrm{~cm} \mathrm{~s}^{-1}$ flow treatment on some occasions, they did not express it as regularly. Apparently, corals growing at higher water-flow rates are less often disturbed in growth by competing algae or cyanobacteria, and will grow more often with higher specific growth rate. Therefore, a combination of the individual growth potential under the given environmental conditions, and the individual presence of disturbances, will determine the resulting specific growth rate. Although differential energy allocation might be a possible explanation for our contradictory findings (increased growth but decreasing phototrophic metabolism), more research is needed to confirm 
this. It is expected that phototrophic feeding and the modulation of photosynthesis by water flow becomes more important at high irradiance. Further research describing the interaction between water flow and irradiance is necessary.

\section{Water flow and skeletal density}

Skeletal density was significantly lower in the absence of flow. This can be considered abnormal, since the corals in the $0 \mathrm{~cm} \mathrm{~s}^{-1}$ flow treatment were unhealthy at the time of sampling. They had very little pigmentation and a lower tissue biomass, which occurs in bleached corals (Szmant and Gassman 1990).

Galaxea fascicularis developed a denser skeleton at higher flow regimes. However, the absence of significant differences in skeletal density with increasing flow rate (10, $20,25 \mathrm{~cm} \mathrm{~s}^{-1}$ ) suggests that they do not further strengthen their skeleton to withstand physical damage from hydrodynamic energy in this range of flow. In contrast, a positive relation between increasing water flow or hydraulic energy and skeletal density was found for different coral species by Schumacher and Plewka 1981, Scoffin et al. 1992, and Smith et al. 2007. Besides living primarily on relatively protected reef sites, G. fascicularis is also known to occur on current-swept reefs, for example in the Tiran Straits (Genin and Karp 1994), where flow speeds are expected to be much higher than $25 \mathrm{~cm} \mathrm{~s}^{-1}$ (average current speed in water column $43 \mathrm{~cm} \mathrm{~s}^{-1}$, with maximum recorded speed $>100 \mathrm{~cm} \mathrm{~s}^{-1}$, Murray et al. 1984). Possibly, the threshold level of water flow for increasing skeletal density was not yet reached for $G$. fascicularis. Additionally, it might not be necessary for a massive mound-shaped coral like G. fascicularis to increase skeletal strength in the tested range of flow regimes, since its growth form does not obstruct the water flow as much as branching corals.

Acknowledgments This research is part of the European CORALZOO project that aims at improving coral husbandry techniques for sustainable coral breeding in zoo's and public aquaria. We thank the staff of Burgers Ocean for their help in setting up the experiment. This work was funded by the European Commission (Project CORALZOO-012547).

Open Access This article is distributed under the terms of the Creative Commons Attribution Noncommercial License which permits any noncommercial use, distribution, and reproduction in any medium, provided the original author(s) and source are credited.

\section{References}

Anthony KRN, Fabricius KE (2000) Shifting roles of heterotrophy and autotrophy in coral energetics under varying turbidity. J Exp Mar Biol Ecol 252:221-253
Anthony KRN, Connolly SR, Willis BL (2002) Comparative analysis of energy allocation to tissue and skeletal growth in corals. Limnol Oceanogr 47:1417-1429

Atkinson MJ, Bilger RW (1992) Effects of water velocity on phosphate uptake in coral reef-flat communities. Limnol Oceanogr 37:273-279

Atkinson MJ, Kotler E, Newton P (1994) Effects of water velocity on respiration, calcification and ammonium uptake of a Porites compressa community. Pac Sci 48:296-303

Box SJ, Mumby PJ (2007) Effect of macroalgal competition on growth and survival of juvenile Caribbean corals. Mar Ecol Prog Ser 342:139-149

Bruno JF, Edmunds PJ (1998) Metabolic consequences of phenotypic plasticity in the coral Madracis mirabilis (Duchassaing and Michelotti): the effect of morphology and water flow on aggregate respiration. J Exp Mar Biol Ecol 229:187-195

Bucher DJ, Harriott VJ, Roberts LG (1998) Skeletal micro-density, porosity and bulk density of acroporid corals. J Exp Mar Biol Ecol 228:117-136

Davies PS (1989) Short-term growth measurements of corals using an accurate buoyant weighing technique. Mar Biol 101:389-395

Dennison WC, Barnes DJ (1988) Effect of water motion on coral photosynthesis and calcification. J Exp Mar Biol Ecol 115:67-77

Finelli CM, Helmuth BST, Pentcheff ND, Wethey DS (2006) Water flow influences oxygen transport and photosynthetic efficiency in corals. Coral Reefs 25:47-57

Furla P, Galgani I, Durand I, Allemand D (2000) Sources and mechanisms of inorganic carbon transport for coral calcification and photosynthesis. J Exp Biol 203:3445-3457

Gattuso JP, Jaubert J (1990) Effect of light on oxygen and carbon dioxide fluxes and on metabolic quotients measured in situ in a zooxanthellate coral. Limnol Oceanogr 35:1796-1804

Genin A, Karp L (1994) Effects of flow on competitive superiority in scleractinian corals. Limnol Oceanogr 39:913-924

Glynn PW, Perez M, Gilchrist SL (1985) Lipid decline in stressed corals and their crustacean symbionts. Biol Bull 168:276-284

Harland AD, Davies PS, Fixter LM (1992) Lipid content of some Caribbean corals in relation to depth and light. Mar Biol 113:357-361

Helmuth B, Sebens KP (1993) The influence of colony morphology and orientation to flow on particle capture by the scleractinian coral Agaricia agaricites (Linnaeus). J Exp Mar Biol Ecol 165:251-278

Jeffrey SW, Humphrey GF (1975) New spectrophotometric equations for determining chlorophylls a, b, c 1 and c 2 in higher plants, algae and natural phytoplankton. Biochem Physiol Pflanz 167:S191-S194

Jokiel PL (1978) Effects of water motion on reef corals. J Exp Mar Biol Ecol 35:87-97

Khalesi MK, Beeftink HH, Wijffels RH (2007) Flow-dependent growth in the zooxanthellate soft coral Sinularia flexibilis. J Exp Mar Biol Ecol 351:106-113

Kuffner IB (2001) Effects of ultraviolet radiation and water motion on the reef coral, Porites compressa Dana: a flume experiment. Mar Biol 138:467-476

Kuffner IB, Walters LJ, Becerro MA, Paul VJ, Ritson-Williams R, Beach KS (2006) Inhibition of coral recruitment by macroalgae and cyanobacteria. Mar Ecol Prog Ser 323:107-117

Lesser MP, Weis VM, Patterson MR, Jokiel PL (1994) Effects of morphology and water motion on carbon delivery and productivity in the reef coral, Pocillopora damicornis (Linnaeus): Diffusion barriers, inorganic carbon limitation, and biochemical plasticity. J Exp Mar Biol Ecol 178:153-179

McCook LJ, Jompa J, Diaz-Pulido G (2001) Competition between corals and algae on coral reefs: a review of evidence and mechanisms. Coral Reefs 19:400-417 
Montebon ARF, Yap HT (1997) Metabolic responses of the scleractinian coral Porites cylindrica Dana to water motion. II. Growth studies. In: Proceedings of 8th International Coral Reef symposium, vol 2. pp 1065-1070

Murray SP, Hecht A, Babcock A (1984) On the mean flow of the Tiran Straits in winter. J Mar Res 42:265-287

Nakamura T, van Woesik R (2001) Water-flow rates and passive diffusion partially explain differential survival of corals during the 1998 bleaching event. Mar Ecol Prog Ser 212:301-304

Nakamura T, Yamasaki H (2005) Requirement of water-flow for sustainable growth of Pocilloporid corals during high temperature periods. Mar Pollut Bull 50:1115-1120

Nakamura T, Van Woesik R, Yamasaki H (2005) Photoinhibition of photosynthesis is reduced by water flow in the reef-building coral Acropora digitifera. Mar Ecol Prog Ser 301:109-118

Patterson MR (1992) A chemical engineering view of cnidarian symbioses. Am Zool 32:566-582

Patterson MR, Sebens KP, Olson RR (1991) In situ measurements of flow effects on primary production and dark respiration in reef corals. Limnol Oceanogr 36:936-948

Rex A, Montebon F, Yap HT (1995) Metabolic responses of the scleractinian coral Porites cylindrica Dana to water motion. I. Oxygen flux studies. J Exp Mar Biol Ecol 186:33-52

Rinkevich B, Avishai N, Rabinowitz C (2005) UV incites diverse levels of DNA breaks in different cellular compartments of a branching coral species. J Exp Biol 208:843-848

Rogers CS (1990) Responses of coral reefs and reef organisms to sedimentation. Mar Ecol Prog Ser 62:185-202

Schumacher H, Plewka M (1981) The adaptive significance of mechanical properties versus morphological adjustments in skeletons of Acropora palmata and Acropora cervicornis (Cnidaria, Scleractinia). In: Proceedings of 4th international coral reef symposium. pp 121-128

Schutter M, Van Velthoven B, Janse M, Osinga R, Janssen M, Wijffels R, Verreth J (2008) The effect of irradiance on longterm skeletal growth and net photosynthesis in Galaxea fascicularis under four light conditions. J Exp Mar Biol Ecol 367:7580

Scoffin TP, Tudhope AW, Brown BE, Chansang H, Cheeney RF (1992) Patterns and possible environmental controls of skeletogenesis of Porites lutea, South Thailand. Coral Reefs 11:1-11
Sebens KP (1987) Coelenterata. In: Pandian TJ, Vernberg FJ (eds) Animal energetics, vol 1. Academic Press, New York, pp 55-120

Sebens KP (1997) Adaptive responses to water flow: morphology, energetics and distribution of reef corals. In: Proceedings of 8th international coral reef symposium, vol 2. pp 1053-1058

Sebens KP, Johnson AS (1991) Effects of water movement on prey capture and distribution of reef corals. Hydrobiologia 226:91101

Sebens KP, Witting J, Helmuth B (1997) Effects of water flow and branch spacing on particle capture by the reef coral Madracis mirabilis (Duchassaing and Michelotti). J Exp Mar Biol Ecol 211:1-28

Sebens KP, Grace SP, Helmuth B, Maney EJ Jr, Miles JS (1998) Water flow and prey capture by three scleractinian corals, Madracis mirabilis, Montastrea cavernosa and Porites porites, in a field enclosure. Mar Biol 131:347-360

Sebens KP, Helmuth B, Carrington E, Agius B (2003) Effects of water flow on growth and energetics of the scleractinian coral Agaricia tenuifolia in Belize. Coral Reefs 22:35-47

Shashar N, Kinaneb S, Jokiel PL, Patterson MR (1996) Hydromechanical boundary layers over a coral reef. J Exp Mar Biol Ecol 199:17-28

Sipkema D, Yosef NAM, Adamczewski M, Osinga R, Mendola D, Tramper J, Wijffels RH (2006) Hypothesized kinetic models for describing the growth of globular and encrusting demosponges. Mar Biotechnol 8:40-51

Smith LW, Birkeland C (2007) Effects of intermittent flow and irradiance level on back reef Porites corals at elevated seawater temperatures. J Exp Mar Biol Ecol 341:282-294

Smith LW, Barshis D, Birkeland C (2007) Phenotypic plasticity for skeletal growth, density and calcification of Porites lobata in response to habitat type. Coral Reefs 26:559-567

Stambler N, Popper N, Dubinsky Z, Stimson J (1991) Effects of nutrient enrichment and water motion on the coral Pocillopora damicornis. Pac Sci 45:299-307

Szmant AM, Gassman NJ (1990) The effects of prolonged "bleaching" on the tissue biomass and reproduction of the reef coral Montastrea annularis. Coral Reefs 8:217-224

Thomas FIM, Atkinson MJ (1997) Ammonium uptake by coral reefs: effects of water velocity and surface roughness on mass transfer. Limnol Oceanogr 42:81-88 